\title{
Assessment of the cytotoxic, genotoxic and mutagenic effects of the commercial black dye in Allium cepa cells before and after bacterial biodegradation treatment
}

\author{
Bruna de Campos Ventura-Camargo ${ }^{a}$, Dejanira de Franceschi de Angelis ${ }^{b}$, \\ Maria Aparecida Marin-Morales ${ }^{\text {a, }}$ \\ ${ }^{a}$ Department of Biology, Institute of Biosciences, São Paulo State University (UNESP), Av. 24-A, 1515, Bela Vista, Rio Claro, SP CEP 13506-900, Brazil \\ ${ }^{\mathrm{b}}$ Department of Biochemistry and Microbiology, Institute of Biosciences, São Paulo State University (UNESP), Av. 24-A, 1515, Bela Vista, Rio Claro, SP CEP \\ 13506-900, Brazil
}

\section{H I G H L I G H T S}

- BDCP metabolites generated by bacterial biodegradation induce cellular alterations.

- $\mathrm{BDCP}$ products generated by bacterial degradation are more toxic than the original BDCP.

- Nuclear buds and binucleated cells indicate genotoxic effects.

- BDCP and its metabolites induce high rates of cell death on Allium cepa cells.

\section{A R T I C L E I N F O}

\section{Article history:}

Received 10 October 2015

Received in revised form

5 June 2016

Accepted 24 June 2016

Available online 18 July 2016

Handling Editor: Frederic Leusch

\section{Keywords:}

Azo dyes

Bacterial biodegradation

Chromosome aberrations

Genotoxicity

Mutagenicity

Allium cepa

\begin{abstract}
A B S T R A C T
The present study evaluated the cytotoxic, genotoxic and mutagenic actions of different concentrations (50 and $200 \mu \mathrm{g} / \mathrm{L}$ ) of BDCP (Black Dye Commercial Product) used by textile industries, before and after bacterial biodegradation, by the conventional staining cytogenetic technique and NOR-banding in Allium cepa cells. Differences in the chromosomal and nuclear aberrations and alterations in the number of nucleoli were observed in cells exposed to BDCP with and without the microbial treatment. The significant frequencies of chromosome and nuclear aberrations noted in the tests with bacterially biodegraded BDCP indicate that the metabolites generated by degradation are more genotoxic than the chemical itself. Losses of genetic material characterize a type of alteration that was mainly associated with the action of the original BDCP, whereas chromosome stickiness, nuclear buds and binucleated cells were the aberrations that were preferentially induced by BDCP metabolites after biodegradation. The significant frequencies of cell death observed in the tests with biodegraded BDCP also show the cytotoxic effects of the BDCP metabolites. The reduction in the total frequency of altered cells after the recovery treatments showed that the test organism A. cepa has the ability to recover from damage induced by $\mathrm{BDCP}$ and its metabolites after the exposure conditions are normalized.
\end{abstract}

๑) 2016 Elsevier Ltd. All rights reserved.

\section{Introduction}

Among the different classes of synthetic dyes, the azo dyes have been most widely used, particularly in the textile sector (Kunz et al., $2002)$. These dyes have one or more azo groups $(-\mathrm{N}=\mathrm{N}-)$ associated with one or more aromatic rings in their structures (Wong and

\footnotetext{
* Corresponding author.

E-mail address: mamm@rc.unesp.br (M.A. Marin-Morales).
}

Yuen, 1996).

The pollution caused by effluents that contain azo dyes can cause serious impacts in the environment (Hao et al., 2000). Organisms exposed to azo dyes have shown different cellular alterations, such as chromosome aberrations and micronucleated cells, which demonstrate the genotoxic and mutagenic effects of the product (Caritá and Marin-Morales, 2008; Phugare et al., 2011; Ventura-Camargo et al., 2011; Fernandes et al., 2015). According to Umbuzeiro et al. (2005), assays performed with Salmonella using water samples from a river that receives effluent from a textile 
industry that uses BDCP point to a mutagenic action of this dye. Alves de Lima et al. (2007) showed the mutagenic and carcinogenic potential of a textile azo dye processing plant effluent.

According to Jadhav et al. (2007), Chengalroyen and Dabbs (2013) and Ventura-Camargo and Marin-Morales (2013), different methods for treating effluents that contain azo dyes have been used in an attempt to minimize the problems associated with this type of contamination. The use of biodegradation for the treatment of azo dyes is a process that has been indicated as having great potential for success. However, there is a need to establish an efficient biological treatment that considers the types of enzymes that are able to degrade certain azo dyes (Kunz et al., 2002; Jadhav et al., 2007; Saratale et al., 2011) because they are relatively resistant to biological degradation processes (Martins et al., 2003; Oliveira et al., 2007) due to their complex chemical structure and high light stability (Kim and Shoda, 1999).

Several bacterial species are used for the degradation of azo dyes (Hu, 1998; Saratale et al., 2011; Singh et al., 2015). Under anaerobic conditions, azo dyes can be degraded into recalcitrant aromatic amines (Weber and Adams, 1995). Treatment with bacteria under aerobic conditions is generally efficient at completely mineralizing aromatic amines (Isik and Sponza, 2003; Saratale et al., 2011), although some studies have shown that some azo dyes are more resistant to bacterial attack under aerobiosis conditions (Hu, 1998). Oliveira et al. (2007) showed that BDCP is recalcitrant even under aerobic conditions because components of this compound were detected in effluent samples that were treated by activated sludge systems.

Higher plants are recognized as important biological materials for detecting genotoxic aberrations caused by environmental pollutants (Yi and Meng, 2003). The species Allium cepa constitutes one of the pioneer materials in the study of chromosomal aberrations caused by the action of chemical agents (Levan, 1938) and has been used as an efficient test organism because it presents a genetic pattern that is suitable for genotoxicity tests (Fiskesjö, 1985; Fernandes et al., 2009; Leme et al., 2008; Hoshina and MarinMorales, 2009; Ventura-Camargo et al., 2011). A study performed by Caritá and Marin-Morales (2008) showed the mutagenic potential of certain samples of industrial effluents contaminated by BDCP as well as other pollutants by applying the chromosomal aberration test in A. cepa. Another study (Ventura-Camargo et al., 2011) showed the genotoxic potential of different concentrations of BDCP on A. cepa meristematic cells.

Chromosomal staining techniques have been successfully applied to chromosomal analyses in plants (Tuna et al., 2004) and may provide information about the DNA composition and its arrangement along chromosomes, enabling a more detailed analysis of the structural organization of chromosomes (Kim et al., 2002). Staining with silver nitrate has been used to identify the number of nucleoli and possible active sites of NOR in different plant species (Carvalho and Guerra, 2002; Ventura-Camargo et al., 2011; Mazzeo and Marin-Morales, 2015). The positions of NORs helps researchers gain a better understanding of the chromosomal alterations that were established in each karyotype (Mazzeo and Marin-Morales, 2015). Thus, in cases in which chromosomal aberrations are induced by genotoxic agents, this technique may provide particular sensitivity by easily diagnosing the probable sites of action of these agents and determining the cell aberrations they caused. Ventura-Camargo et al. (2011) showed that BDCP can act in chromosomal regions of $A$. cepa that were or were not associated with rDNA sites using the NOR-banding technique.

Considering that azo dyes and their related products generally have the potential to cause serious damage in the genetic material of exposed organisms and that their mechanisms of action on DNA need to be further investigated, the aim of this study was to analyze the cytotoxic, genotoxic and mutagenic potential of the commercial black dye in root cells of $A$. серa before and after the bacterial biodegradation treatment using the conventional cytogenetic staining technique (chromosomal and nuclear aberrations test) and AgNOR-banding.

\section{Material and methods}

\subsection{Chemicals tested}

We tested the commercial black dye (BDCP - Black Dye Commercial Product), which is an azo dye composed of 3 dyes that belong to the nitro-aminobenzene group (Umbuzeiro et al., 2005): C.I. Disperse Blue $373\left(\mathrm{C}_{21} \mathrm{H}_{21} \mathrm{BrN}_{6} \mathrm{O}_{6} ; \mathrm{CAS} \mathrm{n}^{\circ}\right.$ 51868-46-3), C.I. Disperse Violet $93\left(\mathrm{C}_{18} \mathrm{H}_{19} \mathrm{BrN}_{6} \mathrm{O}_{5} ; \mathrm{CAS} \mathrm{n}^{\circ}\right.$ 268221-71-2) and C.I. Disperse Orange $37\left(\mathrm{C}_{17} \mathrm{H}_{15} \mathrm{Cl}_{2} \mathrm{~N}_{5} \mathrm{O}_{2}\right.$; CAS n ${ }^{\circ}$ 13301-61-6).

\subsection{Treatment solutions}

The concentrations of the commercial black dye $(50 \mu \mathrm{g} / \mathrm{l}$ and $200 \mu \mathrm{g} / \mathrm{l}$ ) were determined by pilot tests to allow viable development of the cytogenetic techniques used in this study. It is important to consider that the concentrations tested are close to those detected in environmental samples derived from a textile industry that used BDCP, as studied by Oliveira et al. (2007).

\subsection{Test organism}

The assays were performed using seeds of a single variety of A. cepa.

\subsection{Bacterial biodegradation treatments}

The biodegradation treatments were performed using a pool of heterotrophic bacteria obtained from a biological wastewater treatment plant. This bacterial pool was added to the Sabouraud liquid culture medium. The microorganisms were previously incubated in a $35{ }^{\circ} \mathrm{C}$ incubator for 3 days. Then, tests were performed in sterilized test tubes, in which the final volume was of $10 \mathrm{~mL}$ for each tube, as follows:

- Blank Tests - Blank 1: $8.0 \mathrm{~mL}$ of culture medium $+2.0 \mathrm{~mL}$ of distilled water; Blank 2: $7.9 \mathrm{~mL}$ of culture medium $+100 \mu \mathrm{L}$ of bacterial suspension $+2.0 \mathrm{~mL}$ of distilled water.

- Tests with the commercial black dye - Concentration of $50 \mu \mathrm{g} / \mathrm{L}$ : $7.9 \mathrm{~mL}$ of culture medium $+100 \mu \mathrm{L}$ of bacterial suspension $+1.5 \mathrm{~mL}$ of distilled water $+0.5 \mathrm{~mL}$ of the stock solution of $100 \mathrm{mg} / \mathrm{L} \mathrm{BDCP}$; concentration of $200 \mu \mathrm{g} / \mathrm{L}: 7.9 \mathrm{~mL}$ of culture medium $+100 \mu \mathrm{L}$ of bacterial suspension $+2.0 \mathrm{~mL}$ of the stock solution of $100 \mathrm{mg} / \mathrm{L}$ BDCP. The stock solution was prepared in distilled water.

The microorganisms were incubated at $35^{\circ} \mathrm{C}$ for four more days. Subsequently, all of the tubes were autoclaved at $1 \mathrm{~atm}$ for $10 \mathrm{~min}$. After this period, the germination assay was performed using A. cepa seeds. All tests were performed in duplicate.

\subsection{A. cepa bioassays}

A. cepa seeds (100 per dish) were germinated at room temperature $\left(21 \pm 4{ }^{\circ} \mathrm{C}\right)$ in Petri dishes covered with filter paper soaked in ultrapure water. When the roots reached $1.5 \mathrm{~cm}$ in length, they were transferred to Petri dishes covered with filter paper soaked in $50 \mu \mathrm{g} / \mathrm{l}$ and $200 \mu \mathrm{g} / \mathrm{l}$ BDCP. Tests with and without the bacterial treatment were conducted. The roots of the negative control 
(ultrapure water, blank 1 and blank 2) and positive $\left(9 \times 10^{-5} \mathrm{M}\right.$ methyl methanesulfonate) (MMS, Sigma-Aldrich, CAS 66-27-3) control and those exposed to the dye remained in the dishes for a period of $20 \mathrm{~h}$. Then, some roots from each dish were collected, and the rest of them were transferred to dishes covered with filter paper soaked in ultrapure water for periods of 48 and $72 \mathrm{~h}$ for the recovery treatments. After the recovery treatments, the remaining roots were collected.

All collected roots were fixed in a mixture of ethanol and acetic acid $(3: 1-v / v)$ for $18 \mathrm{~h}$ at room temperature. Then, the roots were stored in a freshly made fixation solution at $4{ }^{\circ} \mathrm{C}$ before slides were prepared for the conventional staining technique or AgNORbanding.

\subsubsection{Conventional staining assay}

Slides with meristematic root cells were prepared according to the procedure described by Leme and Marin-Morales (2008).

When the slides were analyzed, some cellular abnormalities were observed, such as chromosomal and nuclear aberrations (CNAs). These CNAs were classified as a genotoxicity endpoint (Leme and Marin-Morales, 2009). The presence of micronuclei and chromosome breaks (MN/B) in the meristematic cells of $A$. cepa was considered to be a mutagenic endpoint that was separate from that of the CNAs (Leme et al., 2008). Apoptotic and necrotic cells (AP/NE) were considered cytotoxicity endpoints (Leme et al., 2008). All of the experiments were performed in duplicate, and a total of 10,000 cells were counted per concentration tested per treatment $(20,48$ and 72 h) by counting 500 cells per slide from a total of 20 slides evaluated.

A set of slides for the non-meristematic regions (F1 cells) of the A. cepa roots was prepared using the procedure described by Leme and Marin-Morales (2008) to verify the frequencies of cells with MN. These experiments were also performed in duplicate, and 2000 cells were counted per concentration tested and per treatment ( 20,48 and $72 \mathrm{~h}$ ) by counting 200 cells per slide from a total of 10 slides evaluated.

\subsubsection{AgNOR-banding}

The slides for AgNOR-banding were prepared after the radicular meristems were pretreated with an enzymatic solution of cellulase/ pectinase $(2: 20-\mathrm{v} / \mathrm{v})$ for $60 \mathrm{~min}$. After a bath of $2 \mathrm{~min}$ in distilled water, the meristems were sectioned, placed on slides, covered with coverslips and gently mounted in a drop of $45 \%$ acetic acid. Then, the slides were frozen in liquid nitrogen and the coverslips were removed. The slides were stained using the protocol proposed by Hizume et al. (1980).

Twenty slides per treatment were prepared to evaluate both cell damage and the variations in the number of nucleoli in interphase cells. Approximately 500 cells were analyzed per slide for a total of 10,000 cells per test for each treatment. All of the experiments were performed in duplicate. Comparisons were performed based on the means of the values for the different tests and treatments.

\subsubsection{Statistical analyses}

Statistical analyses were performed using the Kruskal-Wallis test, and a probability of 0.05 was accepted to indicate a significant effect.

\section{Results and discussion}

\subsection{Conventional staining assay}

The significant occurrence of cell death in the meristematic cells of A. cepa indicated that after bacterial biodegradation, BDCP was capable of causing cytotoxic effects in this test organism (Table 1).
Studies performed by Bafana et al. (2009) also showed that the metabolites of an azo dye (Direct Red 28) exhibited greater cytotoxic action after bacterial degradation, as these intermediate compounds induced a significant frequency of HL-60 human cells to undergo cell death. On the other hand, a study conducted by Jadhav et al. (2011) showed that a textile azo dye (remazol red) was capable of reducing the cell viability of meristems of $A$. cepa, but this cytotoxicity was diminished after this dye was treated with the bacterium Pseudomonas aeruginosa. According to Hoshina and Marin-Morales (2009), the disturbance of the cells by chemicals may lead to a complex sequence of events that can result in cell death, whose main morphological features are nuclear fragmentation, increased cytoplasmic volume, vacuolated cytoplasm, and/ or the presence of a heteropyknotic nucleus. Furthermore, according to Donelli et al. (2003), changes in the cell volume are a direct consequence of the alterations in cell membrane permeability, which also seem to be associated with changes in the cytoskeleton. However, the significant reduction in the frequencies of cell death observed after the recovery treatments in ultrapure water (Table 1 ) indicates that the meristems of $A$. cepa can recover from the cytotoxic damage resulting from both the action of the original BDCP and the metabolites generated after bacterial biodegradation.

The CNAs observed in this study were related to genotoxic events because they represent the damage observed in the genetic material of the cells, but there was no effective proof of fixation in the organism, either because they can eventually be repaired or because they are characterized as injuries that can lead to cell death and are not fixed in the subsequent cellular generations after the damage is established. The high and significant frequencies of CNAs (Table 1) observed in the roots exposed to the different tests and treatments with BDCP with and without microbial action showed the genotoxic action of this chemical and corroborated the data presented by Ventura-Camargo et al. (2011) and Caritá and MarinMorales (2008), who observed some chromosomal aberrations in meristematic cells of $A$. cepa resulting from the action of BDCP and of effluents containing BDCP, respectively. Moreover, the highest and significant frequencies of CNAs that were observed in the tests with BDCP treated with bacteria indicate that the metabolites generated by the biodegradation of BDCP are more genotoxic than the original commercial black dye. According to Chung and Stevens (1993), the formation of metabolites by microbial action, which resulted from the reduction of the azo bond of the dyes, is associated with genotoxic events. These metabolites could react with DNA in different manners (Bartsch, 1981; Umbuzeiro et al., 2005). According to Levine (1991), they may interfere with the genetic material of the organisms by forming DNA adducts.

The present study disagrees with some studies that showed that the metabolites generated after the bacterial biodegradation of azo dyes are less genotoxic than the original dye. The AMES test verified complete detoxification of the sulfonated azo dye red HE7B by Bacillus sp. VUS (Dawkar et al., 2010). Jadhav et al. (2011) showed that the sulfonated azo dye remazol red $(500 \mathrm{mg} / \mathrm{l})$ that had been biodegraded by the bacterium Pseudomonas aeruginosa was less genotoxic than the original compound because the frequency of chromosomal aberrations was significantly reduced in the meristematic cells of $A$. cepa bulb roots of that had been treated with the biodegraded dye. A concentration of $500 \mathrm{mg} / \mathrm{l}$ of the textile azo dye redHE3B (reactive red 120 ) that had been previously treated with a bacterial consortium (Providencia sp. and Pseudomonas aeruginosa) was also proven to be less genotoxic toward $A$. cepa cells, showing that the azo dye subjected to bacterial treatment significantly decreased the frequencies of chromosomal aberrations (chromosomal aberration assay) and DNA damage (comet assay) compared to the original dye (Phugare et al., 2011). Prasad and Rao (2013) 
Table 1

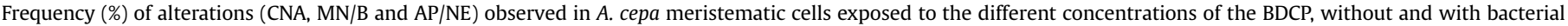
biodegradation, before and after recovery treatments.

\begin{tabular}{|c|c|c|c|c|c|c|c|c|c|}
\hline \multirow{2}{*}{\multicolumn{2}{|c|}{$\begin{array}{l}\text { Treatment } \\
\text { period }\end{array}$}} & \multirow[t]{2}{*}{$\mathrm{NC}$} & \multirow[t]{2}{*}{ PC } & \multicolumn{2}{|c|}{ BDCP concentration $(\mu \mathrm{g} / \mathrm{L})$} & \multirow[t]{2}{*}{ Culture medium } & \multicolumn{3}{|c|}{ Bacterial biodegradation } \\
\hline & & & & 50 & 200 & & $\mathrm{~B}$ & $\mathrm{~B}+\mathrm{A} 50$ & $B+A 200$ \\
\hline \multicolumn{10}{|l|}{$20 \mathrm{~h}$} \\
\hline \multirow[t]{11}{*}{ CNA } & GML & $0.170 \pm 0.016$ & $1.040 \pm 0.012^{\mathrm{a}}$ & $1.310 \pm 0.021^{\mathrm{a}}$ & $1.390 \pm 0.020^{\mathrm{a}}$ & $0.330 \pm 0.015$ & $0.210 \pm 0.011$ & $0.330 \pm 0.013$ & $0.250 \pm 0.016^{\mathrm{b}}$ \\
\hline & $\mathrm{CL}$ & $0.020 \pm 0.010$ & $0.130 \pm 0.013$ & $0.130 \pm 0.013$ & $0.390 \pm 0.019^{a}$ & $0.100 \pm 0.021$ & $0.040 \pm 0.009$ & $0.120 \pm 0.016$ & $0.380 \pm 0.016^{\mathrm{a}}$ \\
\hline & CA & $0.020 \pm 0.010$ & $0.180 \pm 0.010$ & $0.290 \pm 0.018^{a}$ & $0.340 \pm 0.018^{\mathrm{a}}$ & $0.170 \pm 0.016$ & $0.490 \pm 0.026^{\mathrm{a}}$ & $1.800 \pm 0.018^{\mathrm{ab}}$ & $0.670 \pm 0.019^{a}$ \\
\hline & NB & 0 & $0.090 \pm 0.011$ & $0.060 \pm 0.014$ & $0.070 \pm 0.021$ & $0.410 \pm 0.017^{\mathrm{a}}$ & $0.450 \pm 0.012^{\mathrm{a}}$ & $0.900 \pm 0.024^{\mathrm{ab}}$ & $1.820 \pm 0.024^{\mathrm{ab}}$ \\
\hline & $\mathrm{CM}$ & $0.050 \pm 0.010$ & $0.050 \pm 0.010$ & $0.050 \pm 0.010$ & $0.300 \pm 0.015^{\mathrm{a}}$ & $0.110 \pm 0.014$ & $0.250 \pm 0.014$ & $0.250 \pm 0.024$ & $0.740 \pm 0.026^{\mathrm{a}}$ \\
\hline & PM & $0.010 \pm 0.011$ & $0.120 \pm 0.013$ & $0.120 \pm 0.014$ & $0.160 \pm 0.021^{\mathrm{a}}$ & 0 & 0 & 0 & $0.400 \pm 0.018^{\mathrm{a}}$ \\
\hline & PI & $0.010 \pm 0.011$ & $0.050 \pm 0.015$ & $0.120 \pm 0.020$ & 0 & $0.020 \pm 0.022$ & $0.040 \pm 0.025$ & $0.020 \pm 0.016$ & $0.250 \pm 0.020$ \\
\hline & $\mathrm{CB}$ & $0.030 \pm 0.010$ & $0.170 \pm 0.014$ & $0.110 \pm 0.013$ & $0.130 \pm 0.016$ & $0.060 \pm 0.009$ & $0.110 \pm 0.024$ & $0.080 \pm 0.009$ & $0.040 \pm 0.009$ \\
\hline & MU & $0.020 \pm 0.010$ & $0.080 \pm 0.013$ & $0.110 \pm 0.013$ & $0.140 \pm 0.016$ & $0.040 \pm 0.009$ & $0.020 \pm 0.009$ & $0.040 \pm 0.009$ & $0.110 \pm 0.014$ \\
\hline & $\mathrm{BI}$ & 0 & $0.190 \pm 0.012^{\mathrm{a}}$ & $0.080 \pm 0.016$ & $0.060 \pm 0.009$ & 0 & $0.020 \pm 0.014$ & $0.320 \pm 0.021^{\mathrm{a}}$ & $0.480 \pm 0.013^{\mathrm{ab}}$ \\
\hline & CNA & $0.330 \pm 0.015$ & $2.100 \pm 0.015^{\mathrm{a}}$ & $2.380 \pm 0.021^{\mathrm{a}}$ & $2.980 \pm 0.016^{\mathrm{a}}$ & $1.240 \pm 0.014$ & $1.630 \pm 0.013$ & $3.860 \pm 0.013^{\mathrm{a}}$ & $5.140 \pm 0.012^{\mathrm{a}}$ \\
\hline \multirow[t]{3}{*}{ MNB } & MN & $0.210 \pm 0.018$ & $2.220 \pm 0.011^{\mathrm{a}}$ & $1.170 \pm 0.013^{\mathrm{a}}$ & $1.060 \pm 0.027^{\mathrm{a}}$ & $0.480 \pm 0.021$ & $0.230 \pm 0.015$ & $0.290 \pm 0.013$ & $0.510 \pm 0.019$ \\
\hline & $\mathrm{CBr}$ & $0.050 \pm 0.019$ & $0.440 \pm 0.028$ & $0.220 \pm 0.019$ & $0.280 \pm 0.020$ & $0.140 \pm 0.020$ & $0.040 \pm 0.017$ & $0.070 \pm 0.019$ & 0 \\
\hline & $M N B$ & $0.260 \pm 0.010$ & $2.660 \pm 0.022^{a}$ & $1.390 \pm 0.036^{\mathrm{a}}$ & $1.340 \pm 0.018^{\mathrm{a}}$ & $0.620 \pm 0.019$ & $0.270 \pm 0.021$ & $0.360 \pm 0.024$ & $0.510 \pm 0.019$ \\
\hline \multirow[t]{3}{*}{ APNE } & $\mathrm{AP}$ & 0 & $0.030 \pm 0.014$ & 0 & $0.110 \pm 0.000$ & 0 & 0 & 0 & 0 \\
\hline & $\mathrm{NE}$ & 0 & $0.780 \pm 0.033^{\mathrm{a}}$ & $0.990 \pm 0.051^{\mathrm{a}}$ & $1.190 \pm 0.038^{\mathrm{a}}$ & $0.110 \pm 0.021$ & $0.210 \pm 0.033$ & $1.820 \pm 0.045^{\mathrm{a}}$ & $2.190 \pm 0.056^{\mathrm{a}}$ \\
\hline & $A P N E$ & 0 & $0.810 \pm 0.044^{\mathrm{a}}$ & $0.990 \pm 0.051^{\mathrm{a}}$ & $1.300 \pm 0.055^{\mathrm{a}}$ & $0.110 \pm 0.021$ & $0.210 \pm 0.033$ & $1.820 \pm 0.045^{\mathrm{a}}$ & $2.190 \pm 0.056^{\mathrm{a}}$ \\
\hline \multicolumn{2}{|c|}{$\begin{array}{l}\text { Total } \\
\text { Recovery- } 48 \text { h }\end{array}$} & $0.590 \pm 0.043$ & $5.570 \pm 0.026$ & $4.760 \pm 0.057$ & $5.620 \pm 0.062$ & $1.970 \pm 0.034$ & $2.110 \pm 0.036$ & $6.040 \pm 0.038^{a}$ & $7.840 \pm 0.041^{a}$ \\
\hline \multirow[t]{11}{*}{ CNA } & GML & $0.240 \pm 0.018$ & $1.800 \pm 0.014^{\mathrm{ac}}$ & $0.810 \pm 0.034$ & $0.920 \pm 0.031$ & $0.110 \pm 0.020$ & $0.110 \pm 0.019$ & $0.110 \pm 0.024^{c}$ & $0.250 \pm 0.015$ \\
\hline & $\mathrm{CL}$ & $0.080 \pm 0.010$ & $0.250 \pm 0.014$ & $0.070 \pm 0.010$ & $0.160 \pm 0.013$ & $0.060 \pm 0.009$ & $0.080 \pm 0.013$ & $0.130 \pm 0.018$ & $0.160 \pm 0.018$ \\
\hline & CA & $0.070 \pm 0.010$ & $0.130 \pm 0.013$ & $0.280 \pm 0.019$ & $0.140 \pm 0.014$ & $0.080 \pm 0.014$ & $0.110 \pm 0.019$ & $0.990 \pm 0.026^{\mathrm{a}}$ & $0.720 \pm 0.021^{a}$ \\
\hline & NB & $0.010 \pm 0.014$ & $0.080 \pm 0.016$ & $0.060 \pm 0.019$ & $0.060 \pm 0.020$ & $0.600 \pm 0.014^{\mathrm{a}}$ & $0.750 \pm 0.024^{\mathrm{a}}$ & $0.500 \pm 0.036^{a b c}$ & $0.660 \pm 0.018^{\mathrm{ab}}$ \\
\hline & $\mathrm{CM}$ & $0.020 \pm 0.010$ & $0.250 \pm 0.015^{\mathrm{ac}}$ & $0.080 \pm 0.010$ & $0.100 \pm 0.012^{\mathrm{c}}$ & $0.150 \pm 0.018$ & $0.300 \pm 0.019^{\mathrm{a}}$ & $0.150 \pm 0.018$ & $0.190 \pm 0.014$ \\
\hline & PM & $0.010 \pm 0.011$ & $0^{c}$ & $0.060 \pm 0.014$ & $0.100 \pm 0.022$ & 0 & 0 & 0 & $0.040 \pm 0.012^{c}$ \\
\hline & PI & 0 & $0.100 \pm 0.017$ & $0.070 \pm 0.018$ & $0.150 \pm 0.019^{\mathrm{ac}}$ & $0.040 \pm 0.020$ & 0 & $0.060 \pm 0.010$ & $0.130 \pm 0.019$ \\
\hline & $\mathrm{CB}$ & 0 & $0.310 \pm 0.021^{\mathrm{a}}$ & $0.150 \pm 0.017^{\mathrm{a}}$ & $0.100 \pm 0.022$ & $0.020 \pm 0.015$ & $0.020 \pm 0.010$ & $0.120 \pm 0.005$ & $0.210 \pm 0.014^{\mathrm{a}}$ \\
\hline & MU & $0.020 \pm 0.010$ & $0.170 \pm 0.012^{\mathrm{a}}$ & $0.060 \pm 0.010$ & $0.100 \pm 0.014$ & 0 & $0.040 \pm 0.013$ & $0.100 \pm 0.015$ & $0.080 \pm 0.012$ \\
\hline & $\mathrm{BI}$ & 0 & $0.100 \pm 0.014$ & $0.060 \pm 0.009$ & $0.070 \pm 0.009$ & $0.080 \pm 0.009$ & 0 & $0.080 \pm 0.012^{c}$ & $0.140 \pm 0.010^{\mathrm{ac}}$ \\
\hline & CNA & $0.450 \pm 0.018$ & $3.190 \pm 0.013^{\mathrm{ac}}$ & $1.700 \pm 0.022$ & $1.900 \pm 0.016^{\mathrm{a}}$ & $1.140 \pm 0.020$ & $1.410 \pm 0.013$ & $2.240 \pm 0.019^{\mathrm{a}}$ & $2.580 \pm 0.013^{\mathrm{ac}}$ \\
\hline \multirow[t]{3}{*}{ MNB } & MN & $0.210 \pm 0.017$ & $2.450 \pm 0.018^{\mathrm{a}}$ & $0.890 \pm 0.019$ & $1.110 \pm 0.017^{\mathrm{a}}$ & $0.230 \pm 0.021$ & $0.15 \pm 0.014$ & $0.210 \pm 0.023$ & $0.420 \pm 0.020$ \\
\hline & $\mathrm{CBr}$ & $0.010 \pm 0.013$ & $0.300 \pm 0.015^{\mathrm{a}}$ & $0.130 \pm 0.012$ & $0.150 \pm 0.021$ & 0 & $0.02 \pm 0.024$ & $0.020 \pm 0.023$ & $0.020 \pm 0.020$ \\
\hline & $M N B$ & $0.220 \pm 0.012$ & $2.750 \pm 0.049^{\mathrm{a}}$ & $1.020 \pm 0.025$ & $1.260 \pm 0.068^{\mathrm{a}}$ & $0.230 \pm 0.063$ & $0.17 \pm 0.022$ & $0.230 \pm 0.036$ & $0.440 \pm 0.045$ \\
\hline \multirow[t]{3}{*}{ APNE } & $\mathrm{AP}$ & 0 & 0 & 0 & 0 & 0 & 0 & 0 & $0.040 \pm 0.022$ \\
\hline & $\mathrm{NE}$ & 0 & $0.060 \pm 0.027^{c}$ & $0.050 \pm 0.022^{c}$ & $0.460 \pm 0.039^{\mathrm{ac}}$ & $0.290 \pm 0.025$ & $0.73 \pm 0.015^{\mathrm{a}}$ & $0.500 \pm 0.044^{\mathrm{abc}}$ & $0.270 \pm 0.033^{c}$ \\
\hline & $A P N E$ & 0 & $0.060 \pm 0.027^{c}$ & $0.050 \pm 0.022^{c}$ & $0.460 \pm 0.039^{\mathrm{ac}}$ & $0.290 \pm 0.025$ & $0.73 \pm 0.015^{a}$ & $0.500 \pm 0.044^{\mathrm{abc}}$ & $0.310 \pm 0.047^{c}$ \\
\hline \multicolumn{2}{|c|}{$\begin{array}{l}\text { Total } \\
\text { Recovery-72 h }\end{array}$} & $0.670 \pm 0.045$ & $6.000 \pm 0.042^{\mathrm{a}}$ & $2.770 \pm 0.037$ & $3.620 \pm 0.056$ & $1.660 \pm 0.023$ & $2.31 \pm 0.041$ & $2.970 \pm 0.025$ & $3.330 \pm 0.036$ \\
\hline \multirow[t]{11}{*}{ CNA } & GML & $0.190 \pm 0.013$ & $1.190 \pm 0.012^{\mathrm{a}}$ & $0.370 \pm 0.021^{c}$ & $0.690 \pm 0.027$ & $0.020 \pm 0.010$ & $0.120 \pm 0.016$ & $0.150 \pm 0.015$ & $0.200 \pm 0.014$ \\
\hline & $\mathrm{CL}$ & $0.040 \pm 0.014$ & $0.390 \pm 0.012^{\mathrm{ac}}$ & $0.140 \pm 0.014$ & $0.130 \pm 0.016$ & $0.020 \pm 0.010$ & $0.130 \pm 0.016$ & $0.020 \pm 0.009^{c}$ & $0.140 \pm 0.012$ \\
\hline & CA & $0.070 \pm 0.010$ & $0.090 \pm 0.012$ & $0.270 \pm 0.020$ & $0.220 \pm 0.015$ & $0.080 \pm 0.018$ & $0.060 \pm 0.009^{c}$ & $0.270 \pm 0.015^{\mathrm{ac}}$ & $0.920 \pm 0.018^{\mathrm{a}}$ \\
\hline & NB & 0 & $0.080 \pm 0.015$ & $0.070 \pm 0.013$ & $0.070 \pm 0.021$ & $0.350 \pm 0.022^{\mathrm{a}}$ & $0.330 \pm 0.011^{\mathrm{a}}$ & $0.210 \pm 0.016^{\mathrm{ac}}$ & $0.470 \pm 0.028^{\mathrm{abc}}$ \\
\hline & $\mathrm{CM}$ & $0.030 \pm 0.010$ & $0.150 \pm 0.018$ & $0.090 \pm 0.010$ & $0.130 \pm 0.015$ & $0.040 \pm 0.010$ & $0.150 \pm 0.018$ & $0.100 \pm 0.013$ & $0.330 \pm 0.024^{\mathrm{a}}$ \\
\hline & PM & 0 & $0.030 \pm 0.012$ & $0.090 \pm 0.014$ & $0.090 \pm 0.025$ & 0 & 0 & $0.040 \pm 0.012$ & $0.020 \pm 0.022^{c}$ \\
\hline & PI & 0 & $0.080 \pm 0.020$ & $0.120 \pm 0.014$ & $0.160 \pm 0.022^{\mathrm{ac}}$ & $0.120 \pm 0.020$ & $0.040 \pm 0.016$ & $0.040 \pm 0.016$ & $0.210 \pm 0.030^{\mathrm{a}}$ \\
\hline & $\mathrm{CB}$ & $0.010 \pm 0.013$ & $0.110 \pm 0.021$ & $0.080 \pm 0.015$ & $0.130 \pm 0.021^{\mathrm{a}}$ & $0.040 \pm 0.014$ & $0.060 \pm 0.021$ & $0.080 \pm 0.023$ & $0.140 \pm 0.022^{\mathrm{a}}$ \\
\hline & MU & $0.040 \pm 0.012$ & $0.020 \pm 0.015$ & $0.080 \pm 0.016$ & $0.140 \pm 0.022$ & 0 & $0.020 \pm 0.009$ & 0 & $0.100 \pm 0.008$ \\
\hline & $\mathrm{BI}$ & 0 & $0.040 \pm 0.014^{c}$ & $0.060 \pm 0.019$ & $0.090 \pm 0.015$ & 0 & 0 & $0.080 \pm 0.013^{c}$ & $0.120 \pm 0.017^{c}$ \\
\hline & CNA & $0.380 \pm 0.014$ & $2.180 \pm 0.011^{\mathrm{a}}$ & $1.370 \pm 0.018^{c}$ & $1.850 \pm 0.017^{\mathrm{ac}}$ & $0.670 \pm 0.016^{c}$ & $0.910 \pm 0.011^{c}$ & $0.990 \pm 0.013^{c}$ & $2.650 \pm 0.011^{\mathrm{ac}}$ \\
\hline MNB & MN & $0.250 \pm 0.018$ & $2.060 \pm 0.016^{\mathrm{a}}$ & $0.500 \pm 0.011^{c}$ & $1.040 \pm 0.017$ & $0.040 \pm 0.010^{c}$ & $0.080 \pm 0.009^{c}$ & $0.250 \pm 0.011$ & $0.310 \pm 0.018$ \\
\hline & $\mathrm{CBr}$ & $0.010 \pm 0.020$ & $0.130 \pm 0.017^{c}$ & $0.080 \pm 0.015$ & $0.130 \pm 0.004$ & $0.020 \pm 0.024$ & 0 & 0 & $0.020 \pm 0.010$ \\
\hline & $M N B$ & $0.260 \pm 0.014$ & $2.190 \pm 0.047^{\mathrm{a}}$ & $0.580 \pm 0.045^{c}$ & $1.170 \pm 0.039$ & $0.060 \pm 0.009^{c}$ & $0.080 \pm 0.016^{c}$ & $0.250 \pm 0.033$ & $0.330 \pm 0.054^{c}$ \\
\hline APNE & $\mathrm{AP}$ & 0 & $0.020 \pm 0.024$ & $0.050 \pm 0.019$ & $0.020 \pm 0.025$ & 0 & 0 & 0 & $0.140 \pm 0.037$ \\
\hline & $\mathrm{NE}$ & $0.050 \pm 0.034$ & $0.300 \pm 0.019$ & $0.240 \pm 0.026^{c}$ & $0.460 \pm 0.033^{\mathrm{ac}}$ & $0.150 \pm 0.024$ & 0 & $0.090 \pm 0.039^{c}$ & $0.390 \pm 0.028^{\mathrm{ac}}$ \\
\hline & $A P N E$ & $0.050 \pm 0.034$ & $0.320 \pm 0.046$ & $0.290 \pm 0.055^{c}$ & $0.480 \pm 0.061^{\mathrm{ac}}$ & $0.150 \pm 0.024$ & 0 & $0.090 \pm 0.039^{c}$ & $0.530 \pm 0.029^{\mathrm{ac}}$ \\
\hline Total & & $0.690 \pm 0.024$ & $4.690 \pm 0.039^{a}$ & $2.240 \pm 0.044^{c}$ & $3.500 \pm 0.051$ & $0.880 \pm 0.019$ & $0.990 \pm 0.014$ & $1.330 \pm 0.026^{c}$ & $3.510 \pm 0.029$ \\
\hline
\end{tabular}

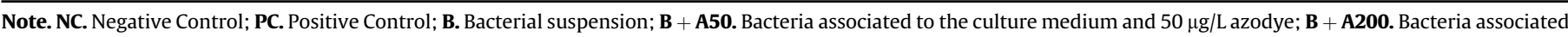

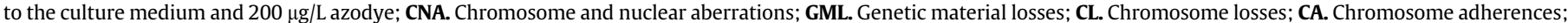

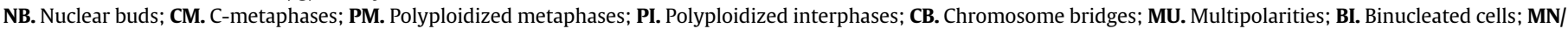

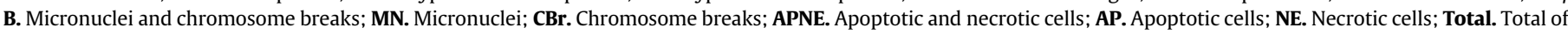
CNA, MNB and APNE.

10,000 cells analyzed for each concentration and treatment. Average \pm Standard Deviation.

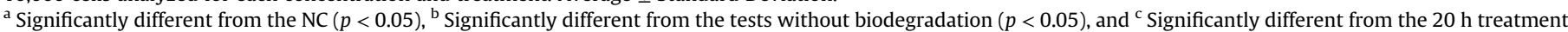
$(p<0.05)$, according to the Kruskal-Wallis test.

showed that the metabolites of the azo dye direct red-22 derived from aerobic biodegradation by Bacillus cohnii MTCC 3616 had negligible cytotoxic and genotoxic effects on $A$. cepa meristematic root tip cells. After the recovery treatments, there was evidence of a reduction in CNA frequencies, as was observed for all of the tests with BDCP (Table 1), which indicates a that $A$. cepa cells may have been able to reverse the genotoxic damage induced by the commercial black dye. 
By considering each type of CNA separately, it was also evident in the $20 \mathrm{~h}$ treatment (Table 1 ) that higher concentrations of the commercial dye induced a significant increase in the CNAs. In addition, significant frequencies of chromosome loss, chromosome adherence, C-metaphase and polyploid metaphases were registered for the tests performed with BDCP. The greater induction of alterations, such as nuclear buds and binucleated cells, for the assays performed after bacterial biodegradation of the highest concentrations of BDCP confirms a more pronounced genotoxic action for this concentration after biodegradation. Regarding the types of CNAs, the most frequent abnormalities caused by the original BDCP were losses of genetic material, whereas the most evident types of cellular alterations after biodegradation were chromosome adherences, nuclear buds and binucleated cells. In the latter case, the types of CNAs must have preferentially originated from the BDCP metabolites. Furthermore, the persistence of the high and significant values of chromosome adherences in the test with the highest concentration of the commercial black dye after biodegradation and recovery reinforces the evidence that shows that the metabolites of this chemical promoted greater genotoxic damage in A. cepa meristematic cells than the commercial black dye that was not bioremediated with these microorganisms.

According to Leme and Marin-Morales (2008), chromosome adherences are common signs of the toxic action of a chemical on genetic material. The effects of this type of alteration are irreversible for cells and can even result in cell death. As shown in Table 1, these alterations (death) were also registered in our analyses. This effect could be induced by BDCP or its metabolites, which prevent chromosomes from migrating to the poles due to their aneugenic action. This action blocks cell division in metaphase following chromosome adherences. For Marcano et al. (2004), these alterations produce bridges and, consequently, chromosome breaks. Chromosome bridges can also result from cohesive chromosomal endings or structural rearrangements (Fiskesjö, 1993). Moreover, chromosome adherences can also lead to chromosome losses (Marcano et al., 2004), which are also considered to be potential causes of aneuploid and polyploid cells. The significant presence of losses of genetic material in prophase in the tests with the nonbiodegraded dye and chromosome losses in metaphase, anaphase and telophase for the highest concentration of BDCP with and without bacterial degradation (20 h treatments) (Table 1) again suggest that both BDCP and its metabolites display aneugenic activity.

C-metaphase can be produced by aneugenic agents, which promote the complete inactivation of the mitotic spindle of the cell (Fiskesjö, 1985, 1993), generating other types of alterations, such as binucleated cells, cells with micronuclei (Fernandes et al., 2007), and polyploid cells (Fernandes et al., 2009). In the present study, cmetaphase was observed at significant frequencies after a $20 \mathrm{~h}$ treatment with the highest concentration of BDCP without bacterial biodegradation and with biodegraded BDCP after $72 \mathrm{~h}$ of recovery (Table 1), corroborating the studies of Caritá and MarinMorales (2008), who showed the presence of c-metaphase and cells with micronuclei after $A$. cepa seeds were exposed to effluents contaminated with the BDCP. These results show that both BDCP and its metabolites from bacterial degradation can interfere with the formation of the mitotic spindle by first inhibiting the organization of the equatorial plate and, consequently, the division of the centromeres, demonstrating proving their aneugenic actions. It is important to also consider that the c-metaphases induced by the treatment with the commercial black dye that had been treated with the microorganisms showed more packed and shorter chromosomes than those induced by the treatment with the dye without bacterial biodegradation (Fig. 1A-B). The presence of this abnormality could be related to the significant frequencies of binucleated and polyploid cells in the roots exposed to BDCP after bacterial degradation (Table 1 ).

According to Fernandes et al. (2007), nuclear buds may be derived from c-metaphase and are alterations that can lead to polyploidization and, consequently, to the formation of micronuclei. According to Shimizu et al. (1998), nuclear buds may also be the result of cellular activities that promote the elimination of the amplified genetic material. Based on analyses in human lymphocytes (Shimizu et al., 1998) and in A. cepa (Fernandes et al., 2007), these authors suggest that amplified DNA from polyploid cells form buds and micronuclei, which may be expelled in the form of "mini cells". In our experiments, significant frequencies of nuclear buds were observed in meristematic cells of $A$. cepa exposed to BDCP after bacterial biodegradation (Table 1; Fig. 1C). We believe that these nuclear buds will be later eliminated in the form of micronuclei, which might be formed by the expulsion of the amplified genetic material and by the additional chromosomes derived from aneuploid cells. Finally, the significant occurrence of nuclear buds could be related to the higher intensity of BDCP aneugenic action after bacterial biodegradation treatment, which proves the more drastic action of its metabolites on the exposed cells.

The mutagenicity of BDCP was estimated by recording the induction of MN/B in meristematic cells of $A$. cepa after exposure to different concentrations of BDCP (Table 1). These alterations are closely associated with mutagenic events because they are alterations in chromosomes or DNA that can be passed on to new cellular generations and can thus be fixed in the organisms (Ventura et al., 2008). The present study showed significant frequencies of MN/B in meristematic cells that were exposed to BDCP for $20 \mathrm{~h}$ before the bacterial biodegradation process, as well as in cells that were exposed to the highest concentration of the commercial black dye that was not treated with these microorganisms and then subjected to the $48 \mathrm{~h}$ recovery treatment (Table 1 ). These data show that this black dye is mutagenic at these concentrations and under these conditions, corroborating the studies performed by Ventura-Camargo et al. (2011). As the chromosome breaks were not significant alterations, the mutagenic effect of BDCP was assigned to the high and significant frequency of micronucleated cells. Oliveira et al. (2007) associated the high values of mutagenic activity in Salmonella to the presence of the commercial black dye in environmental samples of Ribeirão dos Cristais. Studies conducted by Tsuboy et al. (2007) and Chequer et al. (2009) associated the high frequencies of azo dye-induced $\mathrm{MN}$ in animal cells to the mutagenic action of these dyes. Our data show a decrease in the frequencies of MN/B after the recovery treatments, which were only significant at the lower concentration of BDCP in the $72 \mathrm{~h}$ treatment (Table 1), indicating that the mutagenic action of the highest concentration of this chemical has not completely ceased, even after the test organism is no longer exposed to this dosage of the BDCP.

The absence of significant numbers of meristematic cells bearing $\mathrm{MN} / \mathrm{B}$, which were verified in the tests with commercial black dye that had been biodegraded by bacteria (Table 1 ), suggest that the metabolites of this chemical were associated more with the induction of genotoxicity than with mutagenic alterations in these cells. However, due to the high frequencies of MN recorded for the $\mathrm{F}_{1}$ cells that were subjected to a $20 \mathrm{~h}$ exposure to BDCP that had been biodegraded by bacteria followed by $48 \mathrm{~h}$ of recovery (Table 2), it can be inferred that the metabolites of this azo dye promote genotoxic alterations in the meristematic cells that are fixed in the form of cells bearing $\mathrm{MN}$ in the $\mathrm{F}_{1}$ generation, thus confirming the mutagenic effect of these metabolites on $A$. cepa cells. The reduction in the frequencies of these alterations after the $72 \mathrm{~h}$ recovery period (Table 2 ) suggests that the effects of the BDCP metabolites may not be cumulative after the exposure conditions 


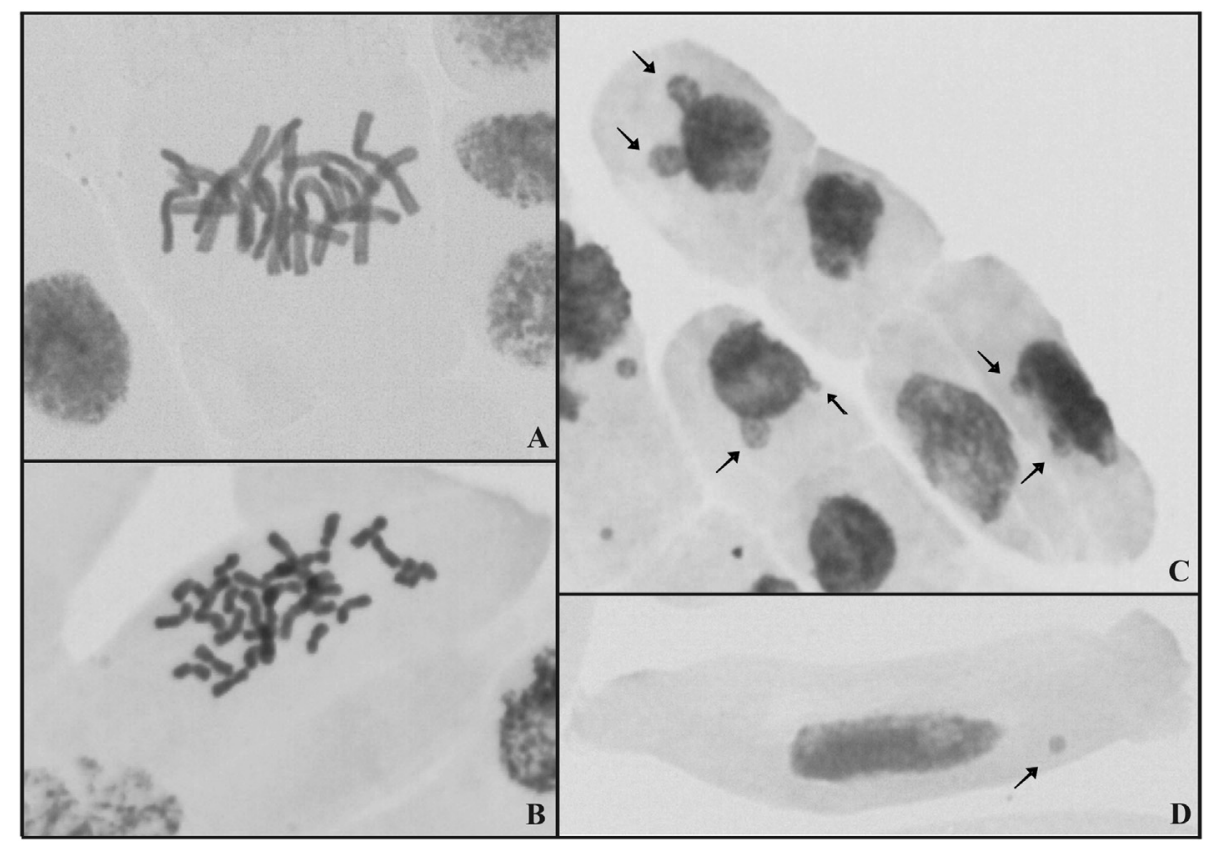

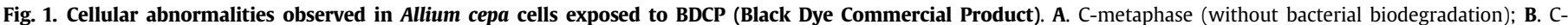
metaphase (with bacterial biodegradation); C. Interphasic cell with nuclear buds (arrows); D. Micronuclei in F1 cell (arrow).

Table 2

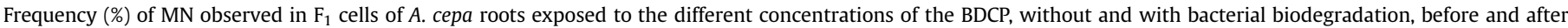
recovery treatments.

\begin{tabular}{|c|c|c|c|c|c|c|c|c|}
\hline \multirow[t]{2}{*}{ Treatment period } & \multirow[t]{2}{*}{ NC } & \multirow[t]{2}{*}{ PC } & \multicolumn{2}{|c|}{ BDCP concentration $(\mu \mathrm{g} / \mathrm{L})$} & \multirow[t]{2}{*}{ Culture medium } & \multicolumn{3}{|c|}{ Bacterial biodegradation } \\
\hline & & & 50 & 200 & & $\mathrm{~B}$ & $\mathrm{~B}+\mathrm{A} 50$ & $B+A 200$ \\
\hline $20 \mathrm{~h}$ & 0.069 & $9.310 \pm 0.072^{\mathrm{a}}$ & $5.020 \pm 0.061^{a}$ & $5.680 \pm 0.057^{\mathrm{a}}$ & $0.960 \pm 0.070$ & $2.050 \pm 0.071$ & $4.380 \pm 0.056^{\mathrm{a}}$ & $4.610 \pm 0.052^{\mathrm{a}}$ \\
\hline Recovery-48 h & $0.290 \pm 0.073$ & $8.070 \pm 0.066^{\mathrm{a}}$ & $2.060 \pm 0.054^{\mathrm{c}}$ & $9.380 \pm 0.057^{\mathrm{ac}}$ & $0.790 \pm 0.071$ & $0.890 \pm 0.066$ & $2.790 \pm 0.058^{\mathrm{ac}}$ & $3.420 \pm 0.057^{a}$ \\
\hline Recovery-72 h & $0.290 \pm 0.073$ & $4.820 \pm 0.056^{\mathrm{ac}}$ & $1.480 \pm 0.062^{c}$ & $5.910 \pm 0.054^{\mathrm{a}}$ & $0.780 \pm 0.088$ & $0.390 \pm 0.049^{c}$ & $1.470 \pm 0.085^{c}$ & $1.180 \pm 0.077^{b c}$ \\
\hline
\end{tabular}

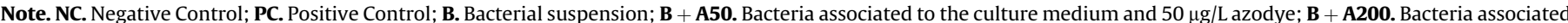
to the culture medium and $200 \mu \mathrm{g} / \mathrm{L}$ azodye.

2000 cells analyzed for each concentration and treatment. Average \pm Standard Deviation.

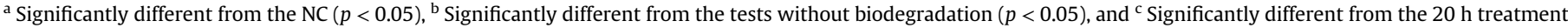
$(p<0.05)$, according to the Kruskal-Wallis test.

are normalized by placing the roots in ultrapure water.

The present study could also confirm the mutagenic action of $\mathrm{BDCP}$ by revealing high frequencies of $\mathrm{MN}$ in $\mathrm{F}_{1}$ cells submitted to a $20 \mathrm{~h}$ BDCP treatment without biodegradation by microorganisms (Table 2; Fig. 1D). The persistence of significant and even higher frequencies of MN in the F1 cells after recovery from the $200 \mu \mathrm{g} / \mathrm{L}$ BDCP treatments (Table 2; Fig. 1D) indicated that the harmful effects observed in the meristematic cells were transferred or fixed to the F1 cells. These mutagenic effects indicate a potential danger of this chemical to the environment because this dosage is probably available in aquatic ecosystems, as it is close to the values that Oliveira et al. reported in environmental samples of industrial effluents (2007).

Overall, based on the cellular abnormalities (CNA, MN/B and AP/ $\mathrm{NE}$ ) observed after the $20 \mathrm{~h}$ treatment (Table 1) with BDCP before and after biodegradation, it was possible to observe a greater toxic potential of the commercial black dye after bacterial action. This result reinforces a more drastic action of the metabolites (including the aromatic amines that were produced from the reduction of the azo bonds) than the dye itself, although both are involved in the induction of the cellular alterations described above. The present study confirms the results reported by Bell et al. (2000), who stated that the increased danger of the secondary compounds generated by microbial degradation results from their higher toxic, mutagenic and carcinogenic potentials compared to the original compound. The reduction in the total frequency of altered cells after the recovery treatments (Table 1 ) shows that the meristems of $A$. cepa are able to recover from the damage induced by the BDCP and its metabolites.

\subsection{AgNOR-banding}

According to Mazzeo and Marin-Morales (2015), nucleolar alterations resulting from the action of either chemical or physical agents can serve as important biomarkers of genotoxicity. After the meristematic cells of $A$. cepa were exposed to BDCP before and after bacterial biodegradation, it was verified that most of the micronuclei presented a nucleolus organizer region. Studies performed by Cermeño et al. (1984) showed that the loss or inactivation of NORs can be related to deletions or translocations. The absence or presence of NORs in the micronuclei of $A$. cepa meristematic cells shows that the dye and its metabolites can act randomly on chromosomes, and therefore may be directly involved at DNAr sites, which are indispensable in transcription and protein translation. These results corroborate studies performed by Ventura-Camargo et al. (2011), which showed that different concentrations of the 
Table 3

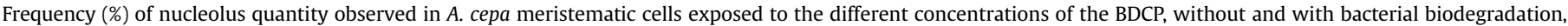
before and after recovery treatments.

\begin{tabular}{|c|c|c|c|c|c|c|c|c|c|}
\hline \multirow{2}{*}{$\begin{array}{l}\text { Treatment } \\
\text { period }\end{array}$} & \multirow{2}{*}{$\begin{array}{l}\text { Nucleolus per } \\
\text { cell }\end{array}$} & \multirow{2}{*}{ NC } & \multirow[t]{2}{*}{ PC } & \multicolumn{2}{|c|}{ BDCP concentration $(\mu \mathrm{g} / \mathrm{L})$} & \multirow[t]{2}{*}{ Culture medium } & \multicolumn{3}{|c|}{ Bacterial biodegradation } \\
\hline & & & & 50 & 200 & & B & $\mathrm{B}+\mathrm{A} 50$ & $\mathrm{~B}+\mathrm{A} 200$ \\
\hline \multirow[t]{8}{*}{$20 \mathrm{~h}$} & 1 & $10.570 \pm 0.011$ & $12.410 \pm 0.011$ & $13.200 \pm 0.011$ & $13.430 \pm 0.012$ & $14.220 \pm 0.010^{\mathrm{a}}$ & $13.600 \pm 0.010$ & $15.190 \pm 0.010^{\mathrm{a}}$ & $13.060 \pm 0.011$ \\
\hline & 2 & $43.620 \pm 0.011$ & $45.370 \pm 0.010$ & $40.930 \pm 0.010$ & $43.090 \pm 0.010$ & $40.100 \pm 0.010$ & $38.570 \pm 0.010$ & $39.310 \pm 0.010$ & $32.900 \pm 0.010^{\mathrm{ab}}$ \\
\hline & 3 & $43.320 \pm 0.010$ & $36.420 \pm 0.010^{\mathrm{a}}$ & $37.860 \pm 0.010$ & $36.070 \pm 0.011^{\mathrm{a}}$ & $39.940 \pm 0.010$ & $42.040 \pm 0.010$ & $35.590 \pm 0.010^{\mathrm{a}}$ & $40.440 \pm 0.010$ \\
\hline & 4 & $1.920 \pm 0.014$ & $4.580 \pm 0.031$ & $6.820 \pm 0.024^{\mathrm{a}}$ & $5.910 \pm 0.012^{\mathrm{a}}$ & $4.580 \pm 0.010$ & $4.020 \pm 0.010$ & $8.080 \pm 0.011^{\mathrm{a}}$ & $10.180 \pm 0.011^{\mathrm{a}}$ \\
\hline & 5 & $0.570 \pm 0.014$ & $0.780 \pm 0.012$ & $1.070 \pm 0.024$ & $1.000 \pm 0.016$ & $0.810 \pm 0.014$ & $1.250 \pm 0.011$ & $1.250 \pm 0.016$ & $2.980 \pm 0.012^{\mathrm{ab}}$ \\
\hline & 6 & 0 & $0.280 \pm 0.010^{\mathrm{a}}$ & $0.100 \pm 0.012$ & $0.460 \pm 0.009^{a}$ & $0.340 \pm 0.010^{\mathrm{a}}$ & $0.510 \pm 0.010^{\mathrm{a}}$ & $0.400 \pm 0.012^{\mathrm{ab}}$ & $0.460 \pm 0.010^{\mathrm{a}}$ \\
\hline & 7 & 0 & $0.130 \pm 0.012^{\mathrm{a}}$ & $0.020 \pm 0.010$ & $0.030 \pm 0.011$ & 0 & 0 & $0.180 \pm 0.010^{\mathrm{a}}$ & 0 \\
\hline & 8 & 0 & $0.030 \pm 0.020$ & 0 & $0.010 \pm 0.011$ & 0 & 0 & 0 & 0 \\
\hline \multirow{8}{*}{$\begin{array}{l}\text { Recovery- } \\
48 \mathrm{~h}\end{array}$} & 1 & $10.740 \pm 0.012$ & $14.270 \pm 0.012$ & $10.690 \pm 0.012^{c}$ & $12.630 \pm 0.012$ & $10.080 \pm 0.011^{c}$ & $12.720 \pm 0.010$ & $12.710 \pm 0.011^{\mathrm{c}}$ & $12.380 \pm 0.010$ \\
\hline & 2 & $39.580 \pm 0.010^{c}$ & $46.470 \pm 0.011^{\mathrm{a}}$ & $36.140 \pm 0.011$ & $34.910 \pm 0.011$ & $33.490 \pm 0.011^{c}$ & $42.880 \pm 0.010^{c}$ & $44.790 \pm 0.010^{a b c}$ & $42.410 \pm 0.010^{c}$ \\
\hline & 3 & $37.280 \pm 0.010^{c}$ & $25.990 \pm 0.012^{\mathrm{ac}}$ & $39.420 \pm 0.010$ & $37.960 \pm 0.009^{c}$ & $45.040 \pm 0.010^{\mathrm{ac}}$ & $35.660 \pm 0.010^{c}$ & $33.990 \pm 0.010^{\mathrm{b}}$ & $36.250 \pm 0.010^{c}$ \\
\hline & 4 & $11.560 \pm 0.014^{c}$ & $9.910 \pm 0.012^{c}$ & $9.780 \pm 0.018$ & $10.690 \pm 0.017$ & $10.040 \pm 0.015^{c}$ & $6.400 \pm 0.010^{\mathrm{ac}}$ & $7.330 \pm 0.011$ & $8.280 \pm 0.010^{c}$ \\
\hline & 5 & $0.780 \pm 0.012$ & $2.860 \pm 0.025^{\mathrm{ac}}$ & $2.870 \pm 0.015^{\mathrm{ac}}$ & $2.410 \pm 0.018^{\mathrm{ac}}$ & $1.130 \pm 0.017$ & $1.620 \pm 0.015$ & $0.850 \pm 0.024^{\mathrm{b}}$ & $0.680 \pm 0.019^{b c}$ \\
\hline & 6 & $0.060 \pm 0.010$ & $0.490 \pm 0.014^{\mathrm{a}}$ & $1.050 \pm 0.010^{\mathrm{a}}$ & $1.370 \pm 0.012^{\mathrm{a}}$ & $0.220 \pm 0.014$ & $0.730 \pm 0.011^{\mathrm{a}}$ & $0.340 \pm 0.014$ & $0^{\mathrm{bc}}$ \\
\hline & 7 & 0 & $0^{c}$ & $0.050 \pm 0.011$ & $0.030 \pm 0.010$ & 0 & 0 & $0^{c}$ & 0 \\
\hline & 8 & 0 & 0 & 0 & 0 & 0 & 0 & 0 & 0 \\
\hline \multirow{8}{*}{$\begin{array}{l}\text { Recovery- } \\
72 \mathrm{~h}\end{array}$} & 1 & $11.340 \pm 0.012$ & $16.350 \pm 0.010^{\mathrm{ac}}$ & $12.970 \pm 0.010$ & $12.750 \pm 0.011$ & $12.110 \pm 0.010$ & $13.920 \pm 0.010$ & $12.030 \pm 0.011^{\mathrm{c}}$ & $12.600 \pm 0.011$ \\
\hline & 2 & $42.580 \pm 0.010$ & $43.030 \pm 0.011$ & $34.550 \pm 0.012^{a}$ & $36.210 \pm 0.012^{c}$ & $38.360 \pm 0.011$ & $36.130 \pm 0.010^{a}$ & $30.190 \pm 0.010^{\mathrm{ac}}$ & $38.190 \pm 0.011$ \\
\hline & 3 & $40.690 \pm 0.010$ & $34.070 \pm 0.011^{\mathrm{a}}$ & $38.950 \pm 0.010$ & $37.400 \pm 0.010$ & $40.130 \pm 0.010$ & $36.730 \pm 0.011^{c}$ & $41.550 \pm 0.010^{c}$ & $37.190 \pm 0.010^{c}$ \\
\hline & 4 & $4.930 \pm 0.013^{c}$ & $6.130 \pm 0.012$ & $11.430 \pm 0.021$ & $11.840 \pm 0.019$ & $8.280 \pm 0.013^{c}$ & $11.750 \pm 0.011^{\mathrm{ac}}$ & $13.680 \pm 0.010^{\mathrm{ac}}$ & $10.470 \pm 0.012^{\mathrm{a}}$ \\
\hline & 5 & $0.300 \pm 0.014^{\mathrm{c}}$ & $0.260 \pm 0.022^{c}$ & $1.920 \pm 0.011^{\mathrm{ac}}$ & $1.480 \pm 0.013^{a}$ & $0.990 \pm 0.016$ & $1.290 \pm 0.012$ & $2.140 \pm 0.011^{\mathrm{ac}}$ & $1.410 \pm 0.012^{\mathrm{a}}$ \\
\hline & 6 & $0.160 \pm 0.010^{c}$ & $0.160 \pm 0.012$ & $0.150 \pm 0.015$ & $0.270 \pm 0.020$ & $0.140 \pm 0.009^{c}$ & $0.180 \pm 0.011^{\mathrm{c}}$ & $0.400 \pm 0.014^{\mathrm{ab}}$ & $0.140 \pm 0.010^{c}$ \\
\hline & 7 & 0 & $0.020 \pm 0.010^{c}$ & $0.050 \pm 0.009$ & 0 & 0 & 0 & $0^{c}$ & 0 \\
\hline & 8 & 0 & 0 & $0.010 \pm 0.011$ & 0 & 0 & 0 & 0 & 0 \\
\hline
\end{tabular}

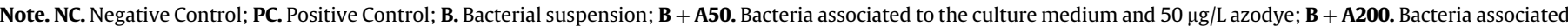
to the culture medium and $200 \mu \mathrm{g} / \mathrm{L}$ azodye.

10,000 cells analyzed for each concentration and treatment. Average \pm Standard Deviation.

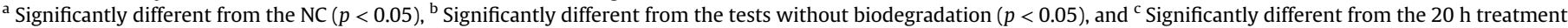
$(p<0.05)$, according to the Kruskal-Wallis test.

original dye act in several chromosomal regions, whether or not they contain DNAr sites. Based on the significant numbers of dead cells and micronuclei bearing NORs observed in the tests performed with the dye before and after bacterial biodegradation, it could be inferred that the loss and, consequently, the lack of chromosomes bearing NORs in the main nucleus can inhibit the physiological activities of the cell, thus leading to death.

According to Arkhipchuk et al. (2000), Ventura-Camargo et al. (2011) and Mazzeo and Marin-Morales (2015), the variation in the number of nucleoli in plants is a result of the action of genotoxic agents. In the present study, the analysis of the number of nucleoli in the A. cepa meristematic cells treated with BDCP (Table 3) showed that the test was an efficient assessment of the genotoxicity of BDCP. A significantly increased number of nucleoli per cell was observed in the cells treated with BDCP compared to the negative control (ultrapure water). Treatments with $200 \mu \mathrm{g} / \mathrm{L}$ nonbioremediated BDCP or the dye that had been bioremediated with bacteria produced significant increases in the frequencies of cells with 6 nucleoli after a $20 \mathrm{~h}$ treatment. Moreover, treatment with $50 \mu \mathrm{g} / \mathrm{L}$ bacterially bioremediated BDCP produced a significant increase in the number of cells with 7 nucleoli. These data suggest that the number of nucleoli observed in this study resulted from the action of the BDCP and its bacterial biodegradation products on cells, confirming the genotoxic action of BDCP and its metabolites, which has already been described for other tests. The recovery treatments minimized the genotoxic effects of these compounds on cells because a significant decrease in the number of cells with 6 nucleoli (treated with $200 \mu \mathrm{g} / \mathrm{L}$ bioremediated BDCP) and 7 nucleoli (treated with $50 \mu \mathrm{g} / \mathrm{L}$ bacterially bioremediated BDCP) was observed after the recovery period (Table 3 ).

\section{Conclusions}

The increased cytotoxic, genotoxic and mutagenic potential of BDCP after bacterial biodegradation are probably due to the formation of aromatic amines resulting from the cleavage of azo bonds.

Although the recovery treatments reduced the frequencies of cytotoxic, genotoxic and mutagenic damage, the effects of the dye and its metabolites were not completely eliminated. These results are a cause for concern, particularly the high rates of cell death promoted by the dye and its metabolites, as well as the proven fixation of the damages caused in cells.

The chromosomal and nuclear aberration assays were very useful in providing information about the different mechanisms of action of BDCP before and after bacterial degradation. The AgNORbanding technique provided some additional information about the genotoxic action of the dye and its metabolites by showing a higher variation in the number of nucleoli in cells treated with BDCP compared with the negative control. Thus, the AgNOR-banding technique is indicated as a complementary methodology for analyzing the toxicity of environmental chemicals.

Our data show that the bacterial biodegradation process is not always efficient and that it can even be more detrimental to the environment by generating toxic metabolites, thus indicating the urgent need to evaluate the effectiveness of biological treatments for industrial effluents.

\section{Conflict of interest}

The authors declare that they have no conflict of interest. 


\section{Acknowledgements}

The authors would like to thank Professor Gisela Umbuzeiro, from Campinas University, for providing them with the BDCP used in this study. In addition, we would like to thank the Secretaria de Educação do Estado de São Paulo for funding this study.

\section{References}

Alves de Lima, R.O., Bazo, A.P., Salvadori, D.M.F., Rech, C.M., Oliveira, D.P., Umbuzeiro, G.A., 2007. Mutagenic and carcinogenic potential of a textile azo dye processing plant effluent that impacts a drinking water source. Mutat. Res. 626, 53-60.

Arkhipchuk, V.V., Malinovskaya, T.T., Garanko, N.N., 2000. Cytogenetic study of organic and inorganic toxic substances on Allium cepa, Lactuca sativa, and Hydra attenuate cells. Environ. Toxicol. 15, 338-344.

Bafana, A., Jain, M., Agrawal, G., Chakrabarti, T., 2009. Bacterial reduction in genotoxicity of Direct Red 28 dye. Chemosphere 74, 1404-1406.

Bartsch, H., 1981. Metabolic activation of aromatic amines and azo dyes. IARC 40, $13-30$.

Bell, J., Plumb, J.J., Buckley, C.A., Stuckey, D.C., 2000. Treatment and decolourization of dyes in anaerobic baffled reactor. J. Environ. Eng. 126, 1026-1032.

Caritá, R., Marin-Morales, M.A., 2008. Induction of chromosome aberrations in the Allium cepa test system caused by the exposure of seeds to industrial effluents contamined with azo dyes. Chemosphere 72, 722-725.

Carvalho, R., Guerra, M., 2002. Cytogenetics of Manihot esculenta Crantz (cassava) and eight related species. Hereditas 136, 159-168.

Cermeño, M.C., Orellana, J., Santos, J.L., Lacadena, J.R., 1984. Nucleolar activity and competition (amphiplasty) in the genus Aegilops. Heredity 53, 603-611.

Chequer, F.M.D., Angeli, J.P.F., Ferraz, E.R.A., Tsuboy, M.S., Marcarini, J.C., Mantovani, M.S., Oliveira, D.P., 2009. The azo dyes Disperse Red 1 and Disperse Orange 1 increase the micronuclei frequencies in human lymphocytes and in HepG2 cells. Mutat. Res. 676, 83-86.

Chengalroyen, M.D., Dabbs, E.R., 2013. The microbial degradation of azo dyes: minireview. World. J. Microbiol. Biotechnol. 29, 389-399.

Chung, K.T., Stevens, J.R., 1993. Degradation of azo dyes by environmental microorganisms and helminths. Environ. Toxicol. Chem. 12, 2121-2132.

Dawkar, V.V., Jadhav, U.U., Jadhav, M.U., Kagalkar, A.N., Govindwar, S.P., 2010. Decolorization and detoxification of sulphonated azo dye Red HE7B by Bacillus sp. VUS. World. J. Microbiol. Biotechnol. 26, 909-916.

Donelli, G., Fiorentini, C., Matarrese, P., Falzano, L., Cardines, R., Mastrantonio, P., Payne, W.P., Titball, R.W., 2003. Evidence for cytoskeletal chages secondary to plasma membrane functional alterations in the in vitro cell response to Clostridium perfringens epilon-toxin. Comp. Immunol. Microbiol. Infect. Dis. 26, $145-156$.

Fernandes, T.C.C., Mazzeo, D.E.C., Marin-Morales, M.A., 2009. Origin of nuclear and chromosomal alterations derived from the action of an aneugenic agent trifluralin herbicide. Ecotoxicol. Environ. Saf. 72, 1680-1686.

Fernandes, F.H., Bustos-Obregon, E., Salvadori, D.M.F., 2015. Disperse Red 1 (textile dye) induces cytotoxic and genotoxic effects in mouse germ cells. Reprod. Toxicol. 53, 75-81.

Fernandes, T.C.C., Mazzeo, D.E.C., Marin-Morales, M.A., 2007. Mechanism of micronuclei formation in polyploidizated cells of Allium cepa exposed to trifluralin herbicide. Pestic. Biochem. Physiol. 88, 252-259.

Fiskesjö, G., 1985. The Allium test as a standard in environmental monitoring. Hereditas 102, 99-112.

Fiskesjö, G., 1993. Technical methods section. Allium test I: a 2-3 Day plant test for toxicity assessment by measuring the mean root growth of onions (Allium cepa L.). Environ. Toxicol. Water Qual. 8, 461-470.

Hao, O.J., Kim, H., Chang, P.C., 2000. Decolorization of wastewater. Environ. Sci. Technol. 30, 449-505.

Hizume, M., Sato, S., Tanaka, A., 1980. A highly reproducible method of nucleolus organizing regions staining in plants. Stain. Technol. 55, 87-90.

Hoshina, M.M., Marin-Morales, M.A., 2009. Micronucleus and chromosome aberrations induced in onion (Allium cepa) by a petroleum refinery effluent and by river water that receives this effluent. Ecotoxicol. Environ. Saf. 72, 2090-2095.

Hu, T.L., 1998. Degradation of azo dye RP2-B by Pseudomonas luteola. Water Sci. Technol. 38, 299-306.

Isik, M., Sponza, D.T., 2003. Effect of different oxygen conditions on decolorization of azo dyes by Escherichia coli, Pseudomonas sp. and fate of aromatic amines. Process Biochem. 38, 1183-1192.

Jadhav, B.S., Phugare, S.S., Patil, P.S., Jadhav, J.P., 2011. Biochemical biodegradation pathway of textile dye Remazol red and subsequent toxicological evaluation by cytotoxicity, genotoxicity and oxidative stress studies. Int. Biodeterior. Biodegr. $65,733-743$.

Jadhav, J.P., Parshetti, G.K., Kalme, S.D., Govindwar, S.P., 2007. Decolourization of azo dye methyl red by Saccharomyces cervisiae MTCC 463. Chemosphere 68, 394-400.

Kim, E.S., Punina, E.O., Rodionov, A.V. 2002. Chromosome CPD (PI/DAPI) - and CMA/DAPI - banding patterns in Allium cepa L. Russ. J. Genet. 38, 392-398.

Kim, S.J., Shoda, M., 1999. Decolorization of molasses and a dye by a newly isolated strain of the fungus Geotrichum candidum Dec 1. Biotechnol. Bioeng. 62, $114-119$.

Kunz, A., Peralta-Zamora, P., Moraes, S.G., Durán, N., 2002. Degradation of reactive dyes by the system metallic iron/hydrogen peroxide. Quím. Nova 25, 78.

Leme, D.M., Angelis, D.F., Marin-Morales, M.A., 2008. Action mechanisms of petroleum hydrocarbons present in waters impacted by an oil spill on the genetic material of Allium cepa root cells. Aquat. Toxicol. 88, 214-219.

Leme, D.M., Marin-Morales, M.A., 2008. Chromosome aberration and micronucleus frequencies in Allium cepa cells exposed to petroleum polluted water - a case study. Mutat. Res. 650, 80-86.

Leme, D.M., Marin-Morales, M.A., 2009. Allium cepa test in environmental monitoring: a review on its application. Mutat. Res. 82, 71-81.

Levan, A., 1938. The effect of colchicine on root mitosis in Allium. Hereditas 24, $471-486$.

Levine, W.G., 1991. Metabolism of azo dyes: implications for detoxication and activation. Drug Metab. Rev. 23, 253-309.

Marcano, L., Carruyo, I., Del Campo, A., Montiel, X., 2004. Cytotoxicity and mode of action of malei hydrazide in root tips of Allium cepa L. Environ. Res. 94 221-226.

Martins, M.A., Lima, N., Silvestre, A.J., Queiroz, M.J., 2003. Comparative studies of fungal degradation of single or mixed bioaccessible reactive azo dyes. Chemosphere 52, 967-973.

Mazzeo, D.E.C., Marin-Morales, M.A., 2015. Genotoxicity evaluation of environmental pollutants using analysis of nucleolar alterations. Environ. Sci. Pollut. Res. 22, 9796-9806.

Oliveira, D.P., Carneiro, P.A. Sakagami, M.K., Zanoni, M.V.B., Umbuzeiro, G.A. 2007. Chemical characterization of a dye processing plant effluent - identification of the mutagenic components. Mutat. Res. 626, 135-142.

Phugare, S.S., Kalyani, D.C., Patil, A.V., Jadhav, J.P., 2011. Textile dye degradation by bacterial consortium and subsequent toxicological analysis of dye and dye metabolites using cytotoxicity, genotoxicity and oxidative stress studies J. Hazard. Mater. 186, 713-723.

Prasad, A.S.A., Rao, K.V.B., 2013. Aerobic biodegradation of azo dye by Bacillus cohnii MTCC 3616; an obligately alkaliphilic bacterium and toxicity evaluation of metabolites by different bioassay systems. Appl. Microbiol. Biotechnol. 97, 7469-7481.

Saratale, R.G., Saratale, G.D., Chang, J.S., Govindwar, S.P., 2011. Bacterial decolorization and degradation of azo dyes: a review. J. Taiwan Inst. Chem. Eng. 42, $138-157$.

Shimizu, N., Itoh, N., Utiyama, H., Wahl, G.M., 1998. Selective entrapment of extrachromosomally amplified DNA by nuclear budding and micronucleation during S phase. J. Cell Biol. 140, 1307-1320.

Singh, R.L., Singh, P.K., Singh, R.P., 2015. Enzymatic decolorization and degradation of azo dyes - a review. Int. Biodeterior. Biodegr. 104, 21-31.

Tsuboy, M.S., Angeli, J.P.F., Mantovani, M.S., Umbuzeiro, G.A., Ribeiro, L.R., 2007. Genotoxic, mutagenic and cytotoxic effects of the commercial dye CI Disperse Blue 291 in the human hepatic cell line HepG2. Toxicol. Vitro 21, 1650-1655.

Tuna, M., Vogel, K.P., Gill, K.S., Arumuganathan, K., 2004. C-banding analysis of Bromus inermis genomes. Crop Sci. 44, 31-37.

Umbuzeiro, G.A., Freeman, H., Warren, S.H., Kummrow, F., Claxton, L.D., 2005 Mutagenicity evaluation of the commercial product C.I. Disperse Blue 291 using different protocols of the Salmonella assay. Food Chem. Toxicol. 43, 49-56.

Ventura, B.C., Angelis, D.F., Marin-Morales, M.A., 2008. Evidences of mutagenic and genotoxic action of the atrazine herbicide using Oreochromis niloticus as test system. Pestic. Biochem. Physiol. 90, 42-51.

Ventura-Camargo, B.C., Maltempi, P.P., Marin-Morales, M.A., 2011. The use of the cytogenetic to identify mechanisms of action of an azo dye in Allium cepa meristematic cells. J. Environ. Anal. Toxicol. 1, 1-12.

Ventura-Camargo, B.C., Marin-Morales, M.A., 2013. Azo dyes: characterization and toxicity - a review. Text. Light Ind. Sci. Technol 2, 85-103.

Weber, E.J., Adams, R.L., 1995. Chemical - and sediment - mediated reduction of the azo dye disperse blue 79. Environ. Sci. Technol. 29, 1163-1170.

Wong, P.K., Yuen, P.Y., 1996. Decolorization and biodegradation of methyl red by Klebsiella pneumoniae RS-13. Water Res. 30, 1736-1744.

Yi, H., Meng, Z., 2003. Genotoxicity of hydrated sulfur dioxide on root tips of Allium sativum and Vicia faba. Mutat. Res. 537, 109-114. 